Portland State University

PDXScholar

Summer 2020

\title{
Exploring Perceptions of Healthcare Quality in Oregon Male Prisons: Interviews with Individuals Recently Released from Long-Term Imprisonment
}

Rén Rosz

Portland State University

Follow this and additional works at: https://pdxscholar.library.pdx.edu/honorstheses

Part of the Criminology and Criminal Justice Commons, and the Medicine and Health Sciences Commons

Let us know how access to this document benefits you.

\section{Recommended Citation}

Rosz, Rén, "Exploring Perceptions of Healthcare Quality in Oregon Male Prisons: Interviews with Individuals Recently Released from Long-Term Imprisonment" (2020). University Honors Theses. Paper 951.

https://doi.org/10.15760/honors.974

This Thesis is brought to you for free and open access. It has been accepted for inclusion in University Honors Theses by an authorized administrator of PDXScholar. Please contact us if we can make this document more accessible: pdxscholar@pdx.edu. 
Exploring Perceptions of Healthcare Quality in Oregon Male Prisons:

interviews with individuals recently released from long-term imprisonment

\author{
by \\ Rén Rosz (Laurén Branstetter)
}

An undergraduate honors thesis submitted in partial fulfillment of the

requirements for the degree of
Bachelor of Science
in
University Honors
and
Pre-Clinical Public Health Sciences

Thesis Adviser

Tina Burdsall

Portland State University 


\begin{abstract}
The healthcare that people who are imprisoned receive is inadequate and does not meet the requirements owed to them by the Eighth Amendment. The Bureau of Justice Statistics has repeatedly surveyed inmates about the health care that they receive (Bureau of Justice Statistics [BJS], n.d.). One of the most recent iterations, in 2004, showed that there were large gaps in the health care that prisoners received: not being able to see a healthcare provider after an injury, necessary medications being discontinued, and lab tests being restricted (Wilper, et al, 2009). The surveys were implemented to highlight policies needing correction and poor conditions (National Archive of Criminal Justice Data [NACJD], 2019). It appears that the data brought about no significant changes in the delivery of healthcare within correctional facilities. In many states, including Oregon, correctional facilities still do not use electronic medical records (EMR). There is little accountability for how these people are cared for, despite it being their constitutional right. This proposal reviews current literature about the healthcare provided in correctional facilities, with a specific focus on prisons. The proposed study would sample people in Oregon who have been recently released from long-term imprisonment (10-25 years) in a male prison. Interviews would be conducted with individuals $(n=25)$ to ascertain their self-rated health status prior to, and throughout their term of imprisonment, as well as the ability to access health care when needed. The interview questions will try to understand the individual's perception of the quality of healthcare that they received.
\end{abstract}

Keywords: abuse of prisoners, justice-involved individuals, eighth amendment, crime and punishment, moral disengagement 


\section{Chapter 1: Intro}

Abuse of prisoners is a pervasive problem in our country. The following examples are just a few of instances that we know about. The federal government led an investigation into dozens of allegations of violent abuse against LA county jails. One deputy, under oath, described multiple instances of guards provoking and attacking inmates with weapons and stun guns to instigate a fight. The guards would then write their reports together later, creating a story to justify the abuse (Kim, 2014). Prisoner abuse commonly takes the form of officers beating or sexually assaulting inmates. However, another form the abuse can take on is when the guards and healthcare providers within the facility ignore prisoners' complaints of illness, restrict or deny medications, or do not provide routine health care checkups.

Dan Brewington was sent to Dearborn County jail for intimidating a judge on his online blog. Dan had ADHD and had long been on Ritalin to manage it. Once imprisoned, the doctor in charge altered his prescribed, established dose after consulting a prescription reference book to determine what the average dosage was. That was done without consulting Dan's regular physician, and sent Dan into debilitating withdrawals (Sonenstein, 2015b).

Kenneth Collins was arrested, in Jackson County, for driving under the influence, with a Blood Alcohol Concentration (BAC) of 0.28 - the legal limit is 0.08 . Kenneth knew that he could go through alcohol withdrawals and requested to be taken to the hospital. Jackson County also has a policy against booking inmates with a BAC over 0.25 without a medical exam and clearance. In this case, the officer ignored both Kenneth's request and the law, took him to the station, and reported that the emergency room had cleared Kenneth to be booked. Kenneth 
went into alcohol withdrawal and very quickly had delirium tremens (DTs), which is a medically severe symptom of alcohol withdrawal with a high mortality rate. Over the next seven days, Kenneth got worse. He saw a nurse, but never a doctor. He was so delirious that he hurt himself, could not stand or use the restroom, did not know where he was, and eventually lost the ability to converse or make eye contact. He had broken ribs, hypothermia, hypertension, acute respiratory failure, dehydration, acute kidney injury, and was having seizures. Kenneth was finally transported to the hospital for possible liver failure, according to the nurse at the jail wrote (Sonenstein, 2015b). Upon arrival, Kenneth was sedated and put on a ventilator. He was kept in the ICU for 14 days and did not regain consciousness for another four days after that.

Brandon Hacker was arrested in Kentucky's Madison County for failing to appear at child support hearings. While in jail, he made a written request for medical attention citing severe stomach pain and nausea. A nurse checked on him and noted that he was sick, shaky, had the chills, and could possibly be withdrawing from heroin. Brandon did not get any other medical attention for forty-eight hours, despite him and his cell mates repeatedly requesting treatment, because the jail did not have a healthcare professional at the facility on weekends. Between Sunday and Monday, three deputies and two different captains at the facility had filed reports recording the serious symptoms that Brandon was presenting. Brandon was finally taken to the med room on Monday morning and the off-site doctor was called, who gave a medication order over the phone. Brandon was unable to eat or drink. His eyes rolled to the back of his head and he was finally rushed to the hospital. He was pronounced dead from a perforated ulcer-a common fatal symptom from heroin withdrawal- an hour after he had been first taken to the med room (Sonenstein, 2015c). 
Tim Strayer was arrested in Dearborn County for possession of marijuana with intent to sell. He was already suffering from multiple illnesses, including: Chronic Obstructive Pulmonary Disease, heart disease, he had one kidney, chronic psoriasis, and acid reflux. However, Tim was still living comfortably with the help of his physicians and proper medications. While in jail, he was not given his heart medication, and became so sick, that he could not breathe, he was vomiting, and became delirious. Tim requested medical attention and was sent to the "defacto" primary-care giver at the facility-an administrative assistant with zero medical training - who did "not know what to do" for him (Sonenstein, 2015a, para. 18). Tim begged to be brought to a hospital, but he was denied. He had not eaten in a week and he knew he had a hernia that needed medical attention. When Tim finally saw the jail's doctor, he was given some medications and blood work was ordered but it was never completed. Tim could not breathe, and he needed an oxygen tank, but the jail simply told him that they did not have one. After he had to stop a short visit from family because he was too sick and weak, the jail had Tim transported to the hospital. When he arrived, Tim was in shock, and was immediately put on a ventilator and declared to be in critical condition. He was sent into emergency surgery right away and again a few days later. He had a stage four decubitus ulcer - a bed sore that had become a large hole with the skin rotted and black, down to the bone. The hospital thought he was an abuse victim; they hadn't known he had come from a jail. Tim ended up staying in the hospital for 196 days. Tim was a seventy-year-old man who hadn't been convicted of any crime, he was just awaiting trial when this happened (Sonenstein, 2015a). Jails, actually, mostly house only unconvicted, pre-trial inmates - an upwards of $85 \%$ of the population in some states (Aiken, 2017). 
Tim's story is extreme, but it is one of many similar accounts of horrendous abuse doled out on people who are imprisoned (Kipnis, 2012; Weill \& Haney, 2017). Robert Jaffe, a highly respected and well-established criminal defense attorney, wrote: "no one is as bad as his worst acts or as good as his best. We are all human beings with relative coping skills, flaws and imperfect personalities" (as quoted in Wallace, 2012, p. 267). People do not commit crimes because they are bad people; most often they are a victim of their circumstance or there is an underlying mental health issue (Kanopy, 2016). Unfortunately, not everyone agrees with the argument of ethics when it comes to caring for inmates. Regardless of the morality of providing adequate healthcare to prisoners, it is still the law. The Supreme Court case, Estelle v. Gamble, ruled that "deliberate indifference" to a prisoner's medical needs does indeed constitute a violation of Eighth Amendment rights (Estelle v. Gamble, 1976). Subsequent cases since then have further guaranteed "services at a level reasonably commensurate with modern medical science and of a quality acceptable within prudent professional standard" (United States v. DeCologero, 2008). Unfortunately, those standards of care are vaguely defined, and it is hard to prove wrongdoing.

The current punitive-focused system that pervades the United States' correctional facilities, promotes moral disengagement among society and justice system professionals, especially those within correctional facilities (Weill \& Haney, 2017). Bandura's mechanisms of moral disengagement are the pathways in which people can distance themselves from a moral issue, and not have to engage with it in a moral capacity. These mechanisms can affect the correctional officer-prisoner relationship. When someone is morally disengaged, they allow otherwise unethical treatment of people and legitimize it. It is a way to morally circumvent an 
issue of mistreatment (Bandura, 1986). This can be seen, not only inside correctional facilities, but in the greater public. These mechanisms mitigate our lack of compassion toward the mistreatment of people who are imprisoned, and how correctional officers mistreat those people to horrifying degrees (Weill \& Haney, 2017).

Those ideologies can be taken to an even more extreme degree in allowing the thinking that prisoners are better off in correctional facilities. This mechanism is known as advantageous comparison: a form of moral disengagement. Bandura explains that theory: when looking at an issue, the lesser of the two evils could be seen as the morally right choice, regardless of how moral it actually is (2016). In the cruelest form, people think that the mistreatment of prisoners is not as bad as the crime the individual committed; this is especially true in heinous, violent crimes. This way of reasoning comes from our socialized acceptance of retribution. Advantageous comparison can also function in allowing the thought that imprisonment is better than receiving the death penalty and at least they have "three hots and a cot" (Weill \& Haney, 2017, p. 298). Although, with the extensive documentation of prisoner abuse (Weill \& Haney, 2017), it seems correctional facilities are not the "liberal paradise" that former Sheriff Joe Arpaio would have people believe (AZQuotes, 2017).

Diffusion of responsibility is another common form of justification of abuse among correctional officers. Law enforcement, including correctional officers, utilizes a top-down hierarchy: a chain of command. Within these chains of command, orders are given by those at the top and implemented and enforced by those at the bottom. The correctional officers that are in facilities and are face-to-face with the imprisoned individuals, are the bottom of the correctional chain. They are trained to follow orders and enforce rules by any means necessary, 
but not to question the morality of their actions (Weill \& Haney, 2017). This idea was also condemned by law in the Nuremberg Trials, in which Nazis were found guilty, regardless of the fact that their atrocities were not their idea and that they were just following orders (The Nuremberg Code, 1949).

The diffusion of responsibility also is created by an "us versus them" mentality, which is prevalent in correctional facilities (Weill \& Haney, 2017). The group identities of a prison guard versus an inmate are deeply ingrained: uniforms, separate bathrooms, break rooms, etc. The group distinction allows officers to distance themselves from the inmates and "others" people who are imprisoned. The individual officer is more likely to act as a group member than their autonomous self (Goffman, 1961). This is dangerous in the correctional facility setting because guards are expected to enforce and punish their deviant inmates. That means, instead of operating within the boundaries of their own morals, they follow the group identity without having to take responsibility for their actions.

These mechanisms and the ideological shift that deprioritizes rehabilitation, leads to a culture that enables the abuse of people who are imprisoned. Not only is this morally reprehensible, but illegal and unethical. This also leads to stigmatization of justice-involved individuals, which discourages the public and policymakers to support their needs.

\section{What is adequate healthcare?}

There is, currently, no "gold standard" defined for healthcare or healthcare benefits. On a surface level, one could assume that adequate healthcare would be that which leads to adequate health. However, health is a nuanced idea that is different in different contexts. The 
World Health Organization (WHO) defines health as "[h]ealth is a state of complete physical, mental and social well-being and not merely the absence of disease or infirmity" (International Health Conference, 2002). If this was the goal of healthcare, there would be almost no reasonable way to limit provisions. The American Medical Association's (AMA) Council on Ethical and Judicial Affairs published some insight to this predicament:

While it may not be possible to define an absolute theory of adequate health care, ethical principles can still guide the determination of adequate health care benefits. There are certain measures of health care benefit that can tell us whether we are meeting the health care needs of individuals and of the larger society... These include the degree of benefit, the likelihood of benefit, the duration of benefit, the number of people who will benefit, and the cost. (1994, p. 1058)

These measurements attempt to map out an ethical way to approach the standards of medical care, alleviating the reservations to take on this issue due to its complicated nature.

The council goes on to define these measurements. The degree of benefit is the comparison of outcome if treatment is given or not. The maximum benefit would be preventing a fatal condition. The well-being achieved by this requirement within individual outcomes is mitigated by comorbidities. The likelihood of benefit has a dual meaning: in treatment it refers to efficacy and in diagnostic testing refers to likelihood that a condition will be found. The positive gains from this requirement, again, are mitigated by the patient's overall health status. Duration of benefit is defined by the ability of a treatment to permanently eliminate a risk or negative outcome, and is also dependent on a person's baseline medical condition. The 
requirements for adequate healthcare reach into a social realm with the number of people benefitting. This can be measured in different ways but primarily by (1) the therapy treats a common medical condition, or (2) the treatment benefits the patient and people with who they come into contact with. Finally, the council touches on cost. They make a point to specify that cost alone is not a reason for approving or denying a treatment, rather the cost relative to the benefit or efficacy of a treatment should be (Council on Ethical and Judicial Affairs, 1994). These measurements are not quite enough to give a clear definition, however, they put us on a path to conceptualizing "adequate healthcare." The requirements are still vague, and intangible ideas like benefit are not always easy to define. The council's attempt to draw healthcare into a more ethical debate, rather than an economic one, is of importance to note. Health has become a business in the US, and in that shift, the importance of ethical treatment has waned in priority to profits.

\section{Goals and Objectives for Research}

This research sets out to glean how people who are imprisoned perceive the quality of healthcare that they are receiving. While there have been national surveys about the health care being offered in correctional facilities, they are inadequate, and do not focus on the quality of healthcare. No research has attempted to understand how people felt about the healthcare that they received. This study is focused on male prisons, as female prisons have more complex needs from their healthcare systems. By focusing on male prisons, the research is able to analyze the disparate experiences of all study subjects together. Additionally, cross sectional analyses can be performed by race-ethnicity and health status prior to imprisonment. 


\section{Implications}

This research has the potential to help build a clearer picture of what quality of healthcare is being delivered in correctional facilities across the United States. Prisoners are at higher risks for poor health outcomes and that could be partially eliminated by providing adequate care. The general public benefits from people being properly cared for, so the results will not just provide individual-level benefits, but population-level benefits. These perceptions combined with national data can help to inform our understanding of what quality of healthcare is being provided to inmates - a constitutionally afforded right.

\section{Overview of Thesis}

The next chapter will explore the current literature about how inmates are treated and cared for in correctional facilities in the United States. The literature will demonstrate how little is known about the quality of healthcare being delivered inside correctional facilities.

Theoretical perspectives will explain how the gap in knowledge was created and why it persists. Chapter three will outline the proposed methodology for gathering the desired data, as well as the limitations of this project and future research possibilities.

\section{A Brief Note on Linguistic Prescription}

The semantics used throughout this proposal are deliberate. They seek to call attention to the importance of prescriptive linguistics, especially when discussing vulnerable populations. This proposal utilizes person-first language (PFL) when appropriate. This is done to counteract the marginalization and stigmatization of people. Any use of the term "criminal" has been omitted, when applicable, and replaced with justice-involved individual. While there was no 
explicit conversion from one term to the other, the shift in language can be found on the US Department of Justice and the US Department of Education websites. It appears this is to utilize PFL and to begin eradicating the stigma of those who have been involved with the justice system. It should be carefully noted that political correctness and prescriptive linguistics are not synonymous. A more sophisticated approach to end discriminatory language is needed, rather than simply "p.c. policing" (Infobase, 2018). 


\section{Chapter 2: Literature Review}

This literature review is divided into three major sections. First, the details of imprisonment will be discussed: how it is supposed to work, what it is supposed to be for, and what is actually happening inside prisons. The next section will show who is imprisoned - on a local and national level - and how that changed, post-mass incarceration. The third section will discuss the health outcomes seen in people who are imprisoned. The final section will provide a brief commentary on the 2020 COVID-19 epidemic, which was occurring at the time of authorship. The progression of this review will outline the systemic inequities and inadequacies of the healthcare system found in correctional facilities.

\section{Imprisonment}

\section{Crime}

Crime, committed or perceived to have been committed, is the entrance to the path of justice system involvement - setting off a chain reaction leading to possible imprisonment (see Figure 1). 


\section{Figure 1:}

"A(n insanely) simplified path of [justice system involvement]"

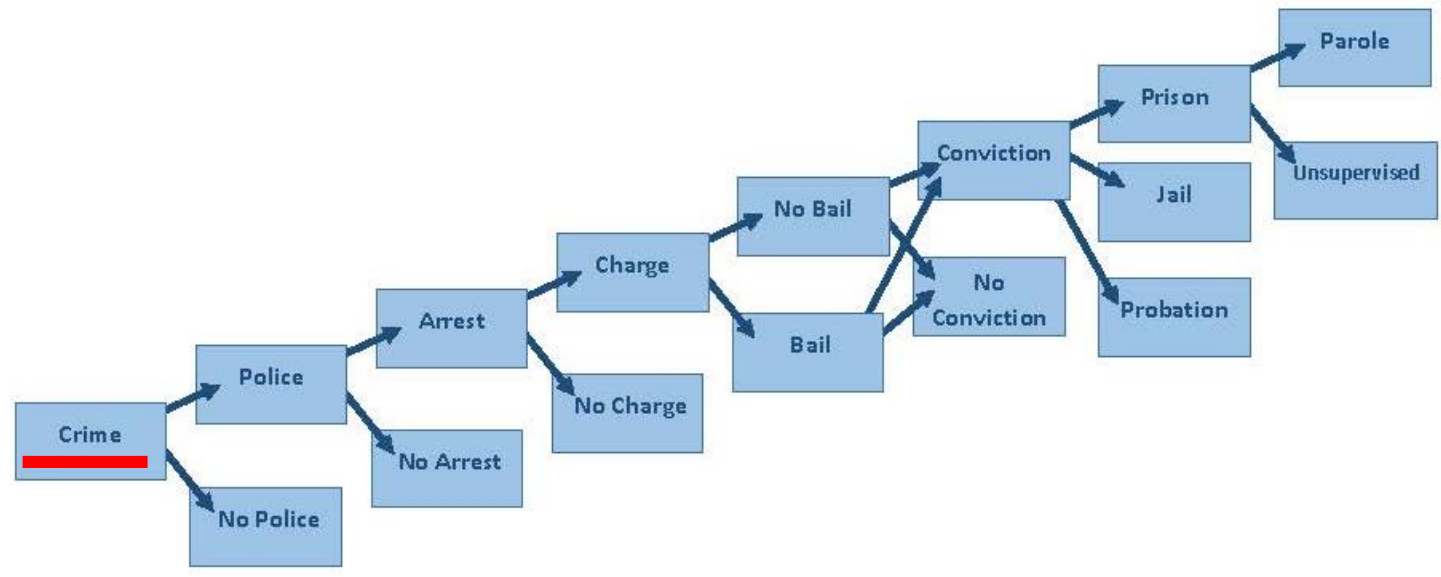

Note. (Wildeman, 2016 as cited in National Academies of Sciences, Engineering, and Medicine, 2017, Figure 2-1)

However, crime is a flexible construct and, as a concept, has been explored by many prominent theorists. Emile Durkheim writes about the need for deviance in a society in his book, The Rules of the Sociological Method. He poses that society must create boundaries on what is acceptable behavior and what is not. Durkheim claims that even in a society of saints, or sin-less creatures, society would simply redefine the boundaries of what was deviant behavior. Durkheim believed crime to be a good thing in society because it helps establish norms and values that people can ascribe to and know when they are outside of them (Durkheim et al., 1964). Not so long ago, identifying as LGBTQ+ was a deviant behavior, punishable by law. The use and possession of marijuana has seen many recent changes in federal and state mandates, as well. Imprisonment has become the universal punishment and it seems that criminal justice policies cannot function without it (Foucault, 1977). However, if deviance is flexible, then the need to imprison must be as well. 


\section{Ideological Shift}

Imprisonment was built on, and justified by, the idea of rehabilitation (Foucault, 1977;

Rothman, 1971). It was meant to provide an "equal" and "autonomous" justice (Foucault, 1977). However, imprisonment is neither equal nor autonomous. Garland (1990) discusses how numerous Marxist studies have demonstrated that imprisonment's real role is in "class-based processes of social and economic regulation." (p. 83). Punishment, specifically imprisonment, is about control, as Foucault and others argue, but even more so about the regulation of socioeconomic status. The ideology around punishment and imprisonment made the system even more unjust, as crime control laws targeted people of color and those of lower socioeconomic statuses (Hinton, 2016).

In the 1960's and 1970's the goal of imprisonment no longer focused on rehabilitation, and that rhetoric faded. The War on Poverty and the War on Crime, during the Johnson-era, set the scene for Nixon, Ford, and Carter to expand on punitive ideology and policies: Draconian sentencing reforms; increased surveillance; and cracking down on repeat offenders (Hinton, 2016). These crime control measures targeted urban neighborhoods of color, and even labelled these youth "potentially delinquent" (Hinton, 2016, p. 4). The War on Drugs, "a fight against crime that seemed to produce only more crime," had the largest hand in the current state of mass incarceration in the US (Hinton, 2016, p. 307). These policies, coupled with questionable social science, ushered in the Reagan-era, and some of the most controversial modern criminal justice policies: namely the Comprehensive Crime Control Act of 1984 which set federal mandatory minimums, procedures for civil asset forfeiture, and cannabis possession sanctions 
(Hinton, 2016). Cullen et al. (2011) shows that with this change of outcomes, there was also a rise in strategies to make the imprisoned suffer in new ways.

The shift to that of a punitive nature, with rehabilitation no longer a priority, expanded the boundaries of acceptable treatment (National Research Council, 2014). One of the advertised goals of imprisonment was to teach justice-involved individuals that "crime does not pay," and the installation of harsh conditions was supposed to create a fear of imprisonment. That ideology was marketed as a deterrent to more extreme crime control laws and longer sentences. However, research shows that we see a cycle of repeat offenders, instead. There is a growing body of evidence showing a criminogenic effect from imprisonment (Cullen et al., 2011). Our penal system may still tote a notion of rehabilitation, but it does not actually have any interventions in place to achieve that (Kanopy, 2016).

\section{Imprisoned Person's Rights}

People who are held in correctional facilities are protected by the Eighth Amendment, which prohibits cruel and unusual punishment. This is supposed to protect those imprisoned from torture and mistreatment, afford them a minimum standard of living, and guarantee them adequate medical care (U.S. Const. amend. IIV; Estelle v. Gamble, 1976; United States v. DeCologero, 2008). While the constitution states "cruel and unusual punishment," it does not define what that means. Subsequent court cases have started to clarify those boundaries.

There are two court cases which are pertinent to discuss for the implications to society, and this research. Estelle v. Gamble (1976) issued one of the first landmark rulings. While the court did not rule in favor of Gamble's claims, it did set a precedence. The court concluded that 
"[d]eliberate indifference by prison personnel to a prisoner's serious illness or injury" is a violation of the Eight Amendment. As shown in the stories from Chapter One, ignoring a prisoner's complaints has become part of the status quo in correctional facilities. In a subsequent case, United States v. DeCologero, again the court did not side with the respondent, but another precedent was set. In the case conclusion, the courts ruled that "it is plain that an inmate deserves adequate medical care" and firmly stated the obligation to provide "services at a level reasonably commensurate with modern medical science and of a quality acceptable within prudent professional standards." This case clearly establishes that correctional facilities must provide a level of care that meets health care standards and should not prevent those imprisoned from accessing the care that they would be able to otherwise. Hence also, the need to establish a "gold standard" of adequate health care. The lack of guidelines and oversight, unfortunately, creates a barrier to proving an Eighth Amendment violation.

There are not extensive checks and balances on the healthcare systems in correctional facilities. "Formal and comprehensive external oversight-in the form of inspections and routine monitoring of conditions that affect the rights of prisoners - is truly rare in this country" (Deitch, 2010, p. 1762). The only recourse an inmate has, if they are wronged, is through 42 U.S.C. section 1983 of the Eighth Amendment. They can sue the county or some of the officers for deliberate indifference. It is called a 1983 claim, colloquially, but those cases are rarely won by the defendants (Robertson, 2015). Wallace states, "[a]s long as the prison official provides some sort of medical attention to the prisoner, the claim is unlikely to result in any kind of relief or remedy for the prisoner" (2012, p. 271). That "medical attention" could be as little as 
denying the patients request or having determined that their condition was not "serious." The wording of the law is so vague that "deliberate indifference" to an inmate's medical needs is hard to prove in court. The "courts are reluctant to provide relief because prisons are meant to punish and amenities that are available to regular citizens are not to be afforded to those who are incarcerated" (Wallace, 2012, p. 271). It is this moral atrocity that keeps our correctional facilities in a vicious circle of perpetrating violence, and cruel and unusual punishment, with no repercussions.

\section{The Demographics of the Imprisoned}

The U.S. imprisons more people than any other country. As of 2019, the rate of imprisonment is 655 per 100,000 people (see Figure 2) (The Sentencing Project, 2019). That is an increase of 500\% over the last forty years (see Figure 3) (The Sentencing Project, 2019). 
Figure 2:

Incarceration rate, per country, per 100,000 in 2019

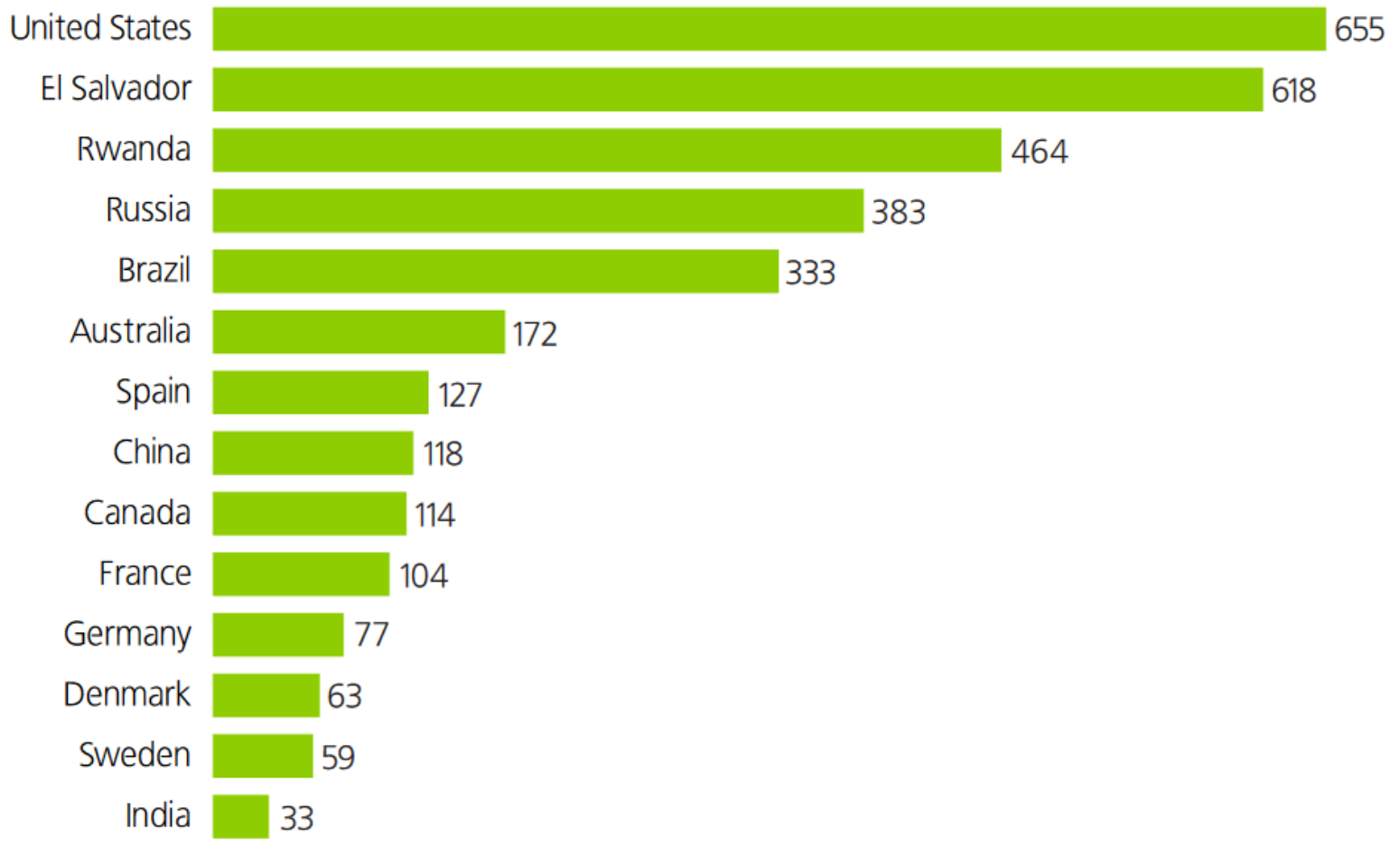

Note. (Walmsley, 2019 as cited in The Sentencing Project, 2019, p. 1) 


\section{Figure 3:}

U.S. State and Federal Prison Population, 1925 - 2017

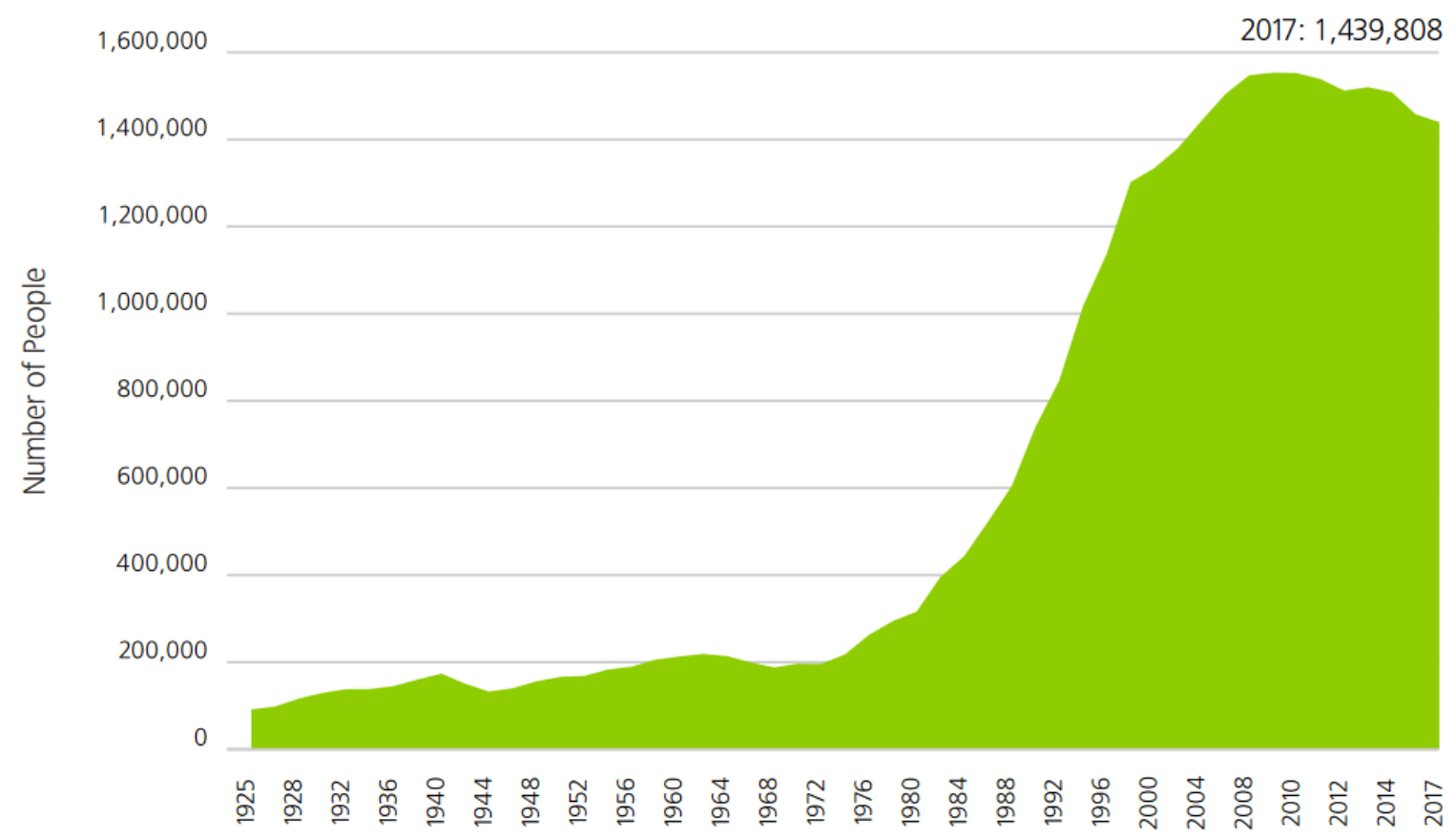

Note. (Bureau of Justice Statistics, as cited in the Sentencing Project, 2019, p. 1)

It is well-documented that the rates of mass imprisonment in our country disproportionately affect people of color (see Figure 4). This is due not only to the racist policies of the War on Crime and the War on poverty, as discussed above, but also the overarching marginalization and inherent racism that still pervades the US society - especially within our institutions and systems (Hinton, 2016; Muhammad, 2011). Muhammad (2011) reports that "Blacks and Latinos in some states represent 90 percent of those admitted to prison for drug offenses...drug prosecutions are a product of the targeting by law enforcement of black and brown inner-city communities in a context of post-civil rights law and order" (pp. 77-78). As described, this targeting has been deep engrained in crime control policies since the 1960's. 
Racial profiling is a real problem, and there have been numerous police and sheriff departments: like in Maricopa County, Arizona; under investigation and reprimanded for it (Poblete, 2018).

\section{Figure 4:}

Rate of imprisonment per 100,00, by Gender and Race-Ethnicity in 2017

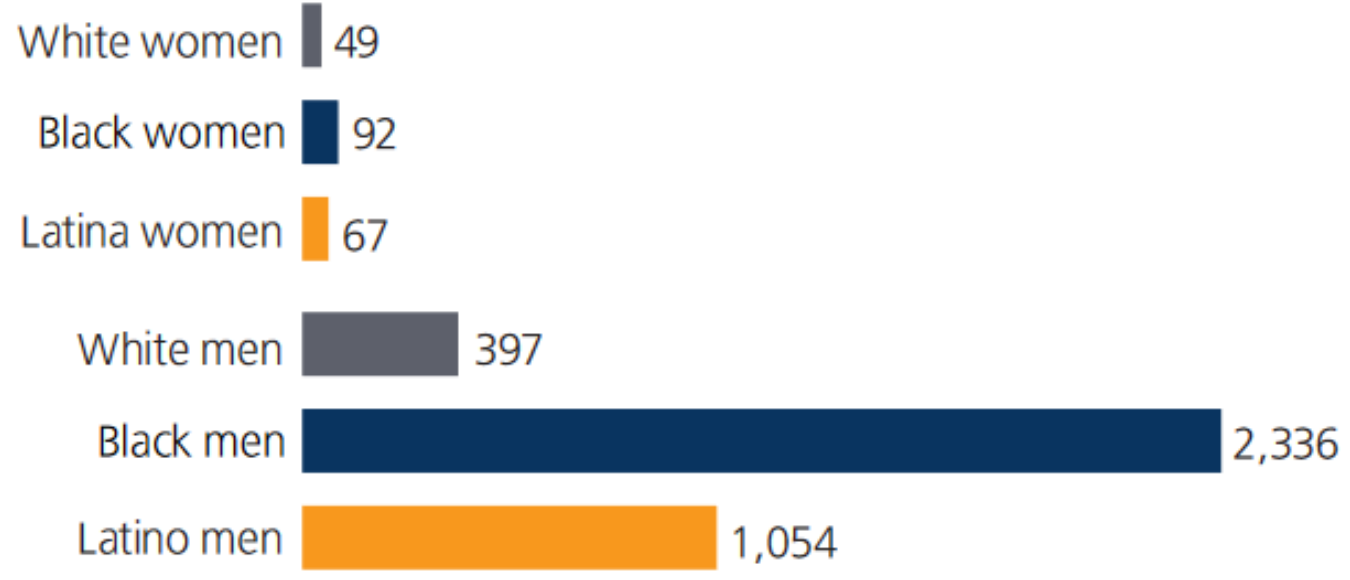

Note. (Bronson \& Carson, 2019, as cited in The Sentencing Project, 2019, p. 5)

These rates show that imprisonment is not an equal opportunity punishment.

\section{Health Outcomes of Justice-Involvement}

These aforementioned statistics have been well-known and discussed for some time, however, it is still not promoting a culture of care in correctional facilities. This is demonstrated through the continuous accounts of prisoner abuse, and the Survey of Prison Inmates (SPI) previously known as the Survey of Inmates in State and Federal Correctional Facilities (SISFCF). The survey was administered seven times by the Bureau of Justice Statistics, most recently in 2016 (BJS, n.d.). The penultimate survey showed that there were still large gaps in the care that 
prisoners received: not being able to see a healthcare provider after an injury, necessary medications being discontinued, and lab tests being restricted (Wilper, et al, 2009). Even after this data was collected, written about, and published, it appears nothing has been implemented to erect change. Smaller studies have been conducted around the nation, showing the amount preventable deaths that justice-involved individuals face, even post-imprisonment.

A study, from Binswanger et al. in Washington, showed the leading causes of death from their cohort to be: cardiovascular disease (CVD), cancer, liver disease, and suicide (see Figure 5). 
Figure 5:

“Mortality Rates among Former and Current Imprisoned Peoples of Washington State Prisons during the Study Period"

\begin{tabular}{|c|c|c|}
\hline Cause of Death & $\begin{array}{l}\text { Former } \\
\text { Inmates }\end{array}$ & $\begin{array}{l}\text { Current } \\
\text { Inmates }\end{array}$ \\
\hline & \multicolumn{2}{|c|}{ no. of deaths $/ 100,000$ person-years } \\
\hline All causes & 777 & 201 \\
\hline Cardiovascular disease & 98 & 68 \\
\hline Atherosclerotic heart disease & 23 & 26 \\
\hline Acute myocardial infarction & 18 & 10 \\
\hline Cerebrovascular disease & 16 & 7 \\
\hline Hypertensive diseases & 16 & 3 \\
\hline Cancer & 68 & 42 \\
\hline Bronchial and tracheal & 33 & 20 \\
\hline Pancreatic & 7 & 6 \\
\hline Liver & 5 & 4 \\
\hline Colon & 0 & 3 \\
\hline Liver disease & 40 & 23 \\
\hline Suicide & 70 & 16 \\
\hline Chronic obstructive pulmonary disease & 9 & 9 \\
\hline Homicide & 95 & 6 \\
\hline Human immunodeficiency virus & 12 & 3 \\
\hline Diabetes mellitus & 11 & 3 \\
\hline Legal intervention involving firearms & 9 & 3 \\
\hline Overdose & 181 & 1 \\
\hline Motor vehicle accidents & 61 & 1 \\
\hline Other accidents & 30 & 1 \\
\hline Other causes & 93 & 25 \\
\hline
\end{tabular}

Note. (Binswanger et al., 2007, Table 5) 
Another study, from North Carolina researchers Jones et al., showed the leading causes of

death to be: cancer, CVD, unintentional motor vehicle injuries, and homicide (see Figure 6).

Figure 6:

"Standard Mortality Ratios of Leading Causes of Death after Release from

Prison in North Carolina, 2008-2010"

\begin{tabular}{|c|c|c|c|c|c|}
\hline \multirow[t]{2}{*}{ Cause of death } & \multicolumn{2}{|c|}{ Deaths } & \multirow[t]{2}{*}{ SMR } & \multicolumn{2}{|c|}{$\mathrm{Cl}(95 \%)$} \\
\hline & Observed & Expected & & & \\
\hline Total deaths-all causes & 926 & 440.71 & 210 & 1.97 & 2.24 \\
\hline Other unintentional Injuries & 205 & 17.43 & 11.76 & 10.23 & 1352 \\
\hline Cancer & 151 & 38.45 & 3.93 & 3.34 & 4.62 \\
\hline ㄴ.p, oral, pharynx & 5 & 0.04 & 117.46 & 38.06 & 273.67 \\
\hline Stomach & 1 & 0.01 & 16.70 & 0.42 & 93.03 \\
\hline Colon, rectum, anus & 11 & 0.56 & 19.76 & 9.86 & 35.37 \\
\hline Liver & 25 & 145 & 17.19 & 11.12 & 25.45 \\
\hline Pancreas & 6 & 0.23 & 26.24 & 9.63 & 57.20 \\
\hline Larynx & 6 & 0.119 & 50.50 & 18.53 & 110.09 \\
\hline Trachea, bronchus, lung & 56 & 5.62 & 9.96 & 756 & 13.03 \\
\hline Mallgrant melanoma of skin & 1 & 0.03 & 34.17 & 0.86 & 190.31 \\
\hline Prostate & 3 & 0.16 & 19.37 & 3.99 & 5655 \\
\hline Bladder & 3 & 0.10 & 31.53 & 6.50 & 92.07 \\
\hline Brain tumor & 3 & 0.03 & 117.23 & 24.15 & 34230 \\
\hline Non-Hodgkins lymphoma & 2 & 0.03 & 67.48 & 8.17 & 243.61 \\
\hline Leukemla & 3 & 0.02 & 147.03 & 30.29 & 429.33 \\
\hline Diseases of the heart & 110 & 24.92 & 4.42 & 3.64 & 5.34 \\
\hline Acute myocardlal infarction & 19 & 1.68 & 1131 & 6.81 & 17.65 \\
\hline Other ischemic heart disease & 56 & 5.31 & 10.54 & 8.00 & 13.79 \\
\hline Hypertension & 3 & 0.08 & 38.06 & 7.84 & mL13 \\
\hline Cerebrovascular disease & 17 & 1.20 & 14.20 & 8.28 & 2273 \\
\hline Atherosclerosis & 1 & 0.01 & 193.27 & 4.89 & 1076.53 \\
\hline Unintentional motor vehicle injuries & 99 & 6.90 & 14.35 & 11.73 & 17.54 \\
\hline Homicide & 77 & 9.65 & 7.98 & 6.34 & 10.03 \\
\hline Suicide & 39 & 2.70 & 14.47 & 10.28 & 19.76 \\
\hline Liver disease/cirrhosis & 37 & 2.139 & 17.30 & 12.17 & 23.83 \\
\hline Dlabetes mellitus & 17 & 0.82 & 20.76 & 12.10 & 33.21 \\
\hline HIV disease & 17 & 2.09 & 8.12 & 4.73 & 1299 \\
\hline Lower respiratory disease & 15 & 0.36 & 41.49 & 23.24 & 68.46 \\
\hline Nephritis, nephrosis & 6 & 0.15 & 40.62 & 14.91 & 88.55 \\
\hline Pneumonia/Influenza & 5 & 0.26 & 19.17 & 6.21 & 44.68 \\
\hline Septicemila & 4 & 0.10 & 40.68 & 11.06 & 104.13 \\
\hline Alzhelmer's disease & 1 & 0.021 & 6153 & 1.56 & 342.74 \\
\hline
\end{tabular}

Note. (Jones et al., 2017, Table 1) 
Both of these studies show that CVD and cancer are leading causes of death for imprisoned and post-imprisoned peoples. While, these data mimic national trends, there are still upstream issues to explore.

Cancer and CVD are not unavoidable diseases. The WHO currently approximates that, of all reported cancer cases, thirty to fifty percent are preventable (2020). The American Heart Association (AHA) has estimated that eighty percent of CVD is preventable (2018). Numerous factors affect the ability to avoid these health outcomes, primarily: dismantling the healthwealth gradient and other social determinants of health. Subsequently, though, access to primary and preventative care is crucial to reduce the rates of these preventable diseases (Smith, 2008). Additionally, Porter (2014) found that people who had been imprisoned at one point in their life, were more likely to smoke and had higher rates of fast food consumptions. Those measurements were used as the indicators for health behavior, and thus extrapolated that negative health behaviors, post-imprisonment, could be a driving force in the health and mortality risks faced by justice-involved individuals (Porter, 2014). While the mortality trends for those who have been imprisoned match national ones, we can see that it is not because health is equitably distributed, but because health is dependent on socioeconomic position - in which high standing is not afforded to the justice-involved population.

\section{Consequences}

The lack of quality healthcare in our correctional facilities affects all of us. Our health and economy improve if prisoners were given the treatment that the constitution affords them (Welsh, Farrington, \& Sherman, 2001; Restum, 2005). If less people were imprisoned, or if the 
system actually rehabilitated offenders, correctional facilities would need less money from taxpayers overall. Additionally, it benefits everyone if there are more people participating in the economy, instead of being imprisoned (Welsh, Farrington, \& Sherman, 2001). Possibly more important than the effects on the economy, are the effects on our health. There is a lack of testing, follow up, and treatment of inmates' ailments and high rates of communicable diseases among that population. If those diseases are not being diagnosed or treated, then individuals are released, that puts their whole community at risk (Restum, 2005). The standards of healthcare in prisons must be improved, not just because of a moral argument, but because we are all at real risk if we do not.

While there are recommendations for testing, the implication is inconsistent and inadequate. According to the 2011 data from the National Survey of Prison Health Care, only some states test some of their incoming individuals for communicable diseases (Karishma et al., 2016). There is not a formal pre-release health screening requirement. There is not a lot of documentation on specific steps for release on a federal level. All state facilities can follow any protocol that their state department deems comprehensive. It seems like, among the few states that have any published information on their prerelease process, mental health screenings and substance abuse counseling are the most common initiatives. No mention of testing, specifically, was found. There have been a few smaller and/or older studies that have concluded in recommendations to include a medical screening, and testing, as part of the prerelease process (Braithwaite et al., 2005; National Commission on Correctional Health Care [NCCHC], 2002; Nijhawan, 2016; Sieck \& Dembe, 2010). However, there are still absent data on the efficacy of these interventions (Nijjhawan, 2016). 
The astronomical imprisonment rates in the US, also yield high release rates. In 2012, 637,400 persons were released from a US prison; compared to releases in 1978, which was around 150,000 persons (Carson \& Golinelli, 2014).

\section{Figure 7:}

"Sentenced State and Federal Prison Admissions and Releases and Yearend Sentenced Prison Population, 1978-2012"

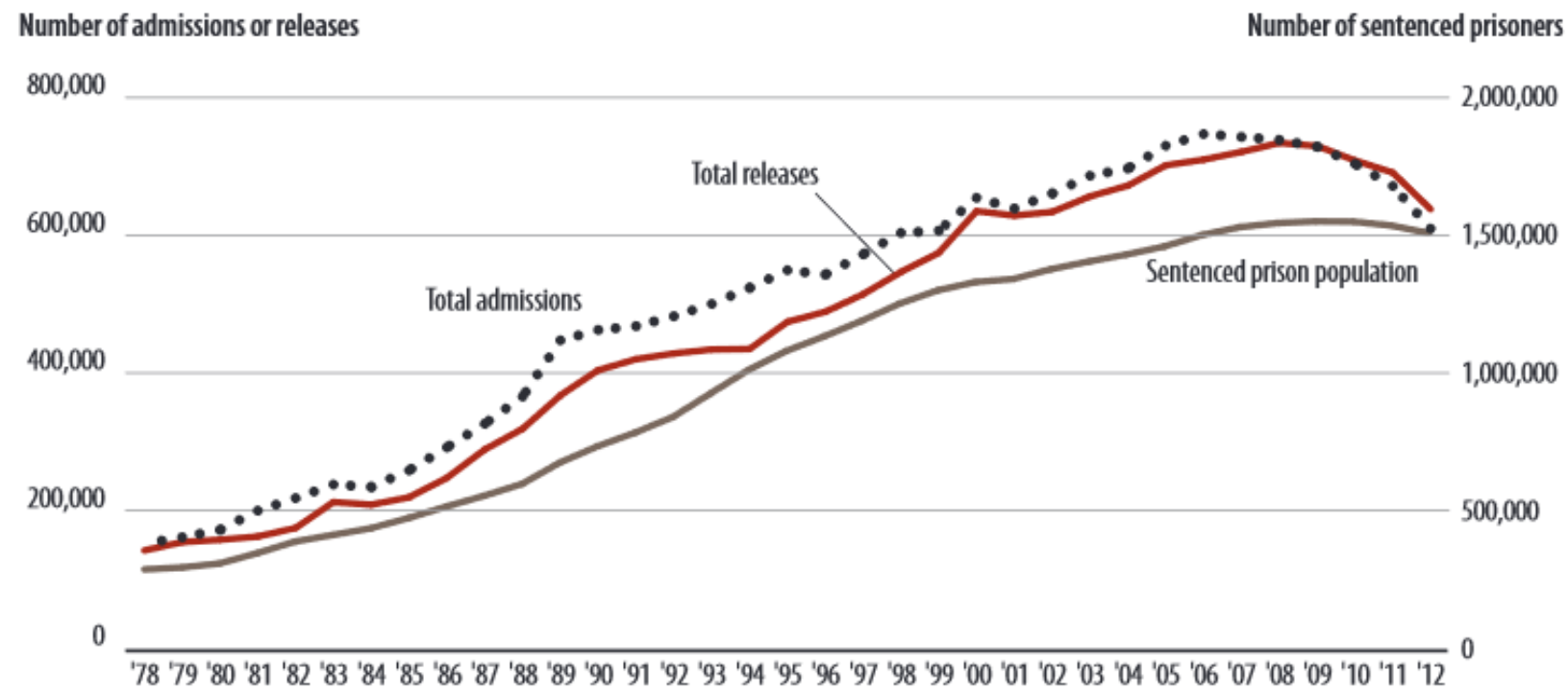

Note. (Carson \& Golinelli, 2014, Figure 1)

There must be health assessment requirements, upon admission and release in prisons across the country. The lack of testing, provision of services, and continuity of care means that we don't know how many people are being released with an untreated, or undiagnosed, communicable disease. Hammett et al. (2002) reported, in 1997, twenty to twenty-six percent of people living with HIV, twenty-nine to forty-three percent of those infected with Hepatitis C, 
and forty percent of those who had Tuberculosis had passed through a US correctional facility.

This is old data, but it is one of the last aggregate reports found.

\section{SARS-CoV-2 Addition, 2020}

This proposal was initially intended to be a completed research project. However, due to the COVID-19 pandemic, data collection had to be suspended. This brief section will provide an update on the current coronavirus situation in correctional facilities in the US.

The Marshall Project, in conjunction with The Associated Press, have been working on tracking COVID-19 sickness and deaths in prisons. As of July $21^{\text {st }}$, at least 70,717 people who are imprisoned have tested positive for COVID-19, and at least 713 have died. There is limited, at best, data for how correctional facility workers are being affected. Through sporadic, and voluntary reporting, at least 15,707 prison staff members have tested positive, and at least fifty-four have died (Park \& Meagher, 2020). For detailed methodology and reporting efforts, navigate to The Marshall Project's website listed in the reference list citation for this source.

The Prison Policy Initiative teamed up with the ACLU to examine state-by-state responses in correctional facilities. Through weighted criteria and reported data, grades were assigned to each state - the highest was a "D-“ (Widra \& Hayre, 2020). For a detailed description of methodology and data points, see the Prison Policy Initiative website listed in the reference list citation for this source.

Multiple organizations and researchers have published suggested guidelines for how to suppress the spread of COVID-19 in correctional facilities (Barr, 2020; Centers for Disease Control and Prevention [CDC], 2020; Wagner \& Widra, 2020; Williams et al., 2020). Ensuring 
mass, and adequate, distribution of PPE and following social distancing guidelines is among the top of every list. Since correctional facilities are massively overcrowded, all of these guidelines have advocated for the release of prisoners. As of July $1^{\text {st }}, 2020$, eleven states have continued to refuse the release of any individuals (Ballotpedia, 2020). As for the appropriate use and distribution of PPE, 37 states out of the 49 evaluated, met the full requirements, according the Prison Policy Initiative/ACLU study (Widra \& Hayre, 2020). From the horrific numbers plaguing the correctional facilities across the country, it is shown that there was an enduring unwillingness to follow the suggested protocols, and the threat was not taken seriously - or simply not cared about.

Author's Note:

Due to the dynamic nature of the coronavirus pandemic - AKA COVID-19-, caused by the SARSCoV-2 virus, this passage was last updated on July $27^{\text {th }}, 2020$. Also, important to regard is the credibility of sources in this section. Most are independent journalists, organizations, and other nonpeer-reviewed creators. Extreme care was taken to find as reputable references as possible, while this is an emerging topic of research.

\section{Theory}

The criminal justice system, and policymakers, bear the burden of maintaining the eighth amendment rights of those who are imprisoned. That is argued to be the social responsibility of the system, its makers, and its actors (Kipnis, 2012). Kipnis (2012) states that this social responsibility is much like the social responsibility parents have to provide access to healthcare for their children, "not [just] because they have a basic right to health care" (p. 375). 
This idea removes the need to justify healthcare as a human right, but instead makes it a social responsibility of the system - which arguably includes the taxpayers and voters in the US. Kipnis backs up these claims by using democratic theory. They show that "the state derives its legitimacy from the consent of the governed, in a deeper sense, those with responsibility for the polity must take care not to discredit their offices and, by implication, the government in whose name they act" (Kipnis, 2012, p. 377). Therein lies the responsibility of the state to ensure that the eight amendment is adhered to. Through social justice, though, healthcare as a human right, must be explored.

It seems understood that humans have a right to life and the human experience. The inadequacy of health care, leads to the inadequacy of health, and an inadequate human existence. Health, thus health care too, leads people to have access to the some of the most important aspects of life: relationships, employment, aesthetic capabilities, political position, and even the capacity to think (Rhodes et al., 2012). We must rely on principles and theory of justice to understand, and argue, the need to view healthcare as a social responsibility, and a human right.

Daniels (2012) points out that access to health care, alone, is not going to solve issues of inequality in health. There is an abundance of evidence and research showing that, what most dictates our health is our social position: socioeconomic status, gender, race-ethnicity, etc. Factors of wealth, stigma, and identity inequalities are what breeds health inequality. Daniels (2012) argues further that, with that knowledge the focus must be on an upstream approach of solving social justice issues. Then we can cement distributive justice within health and healthcare. These theories are based in Daniels' previous work, which he admits to having been 
shortsighted in its conclusion that equal access to healthcare would solve all health inequality issues (Daniels, 2012).

While errors in conclusion may have been made, Daniels (1985), theorizes solution through distributive justice principles. The theory claims caution in the fact that people may not necessarily agree on what dictates "just" healthcare. Daniels (1985) tackles this insurmountable task, with the idea that we can determine the social good of healthcare through the system's function, effects, and quality of life attainment. He posits that once we understand this, we can apply general distributive justice theories to re-design our healthcare system.

Daniels' theories are built on Rawls' (1971) Theory of Justice. Rawls' theory differs from previous ones, such a utilitarianism, because Rawls focuses on a socially just distribution of goods. Rawls, in fact, critiques utilitarianism because of its aptitude to fuse many people as one, and does not originate from an individual's integrity (Rawls, 2013). Rawls' theory harps on not only respecting what is best for most people, but also people's distinct autonomy. The theory of justice centralizes on this distinction.

\section{Conclusions and Interpretations}

It seems obvious that we have a problem with the healthcare delivery system in correctional facilities in the US. People who are afforded equal rights to healthcare are being ignored, abused, and are dying. It is fully expected that a moral obligation and ethical reasoning should be enough to motivate attention and intervention to this problem. In doing that, society will see a return, in general. Not only will our population be healthier, as a whole, but it could mitigate disease for communities, as well as strengthen the national economy. Reducing stigma 
to any population will also add to the quality of life for all. As a society, we are a community. Whether we realize it or not, we feed off each other, and need one another to be well and healthy.

This chapter discussed the literature describing the inadequacies of the healthcare system in correctional facilities. Literature and theory were used to show how the problem arose, and why it persists. The following chapter will outline what, and how, data will be collected, along with the proposed analytical methods. 


\section{Chapter 3: Methods}

This chapter is a proposal for a pilot research study to gain insight into the perception of the quality of healthcare received in Oregon male prisons. Approval from Portland State University Institutional Review Board (IRB) has already been attained. Because Multnomah County is involved with the research, their Research and Planning (RAP) Team has also given its approval of the study design and documents. An overview of the proposed analysis will be provided, as well.

This research is planned as a pilot study to ensure that the design produces outcomes that will best serve the study population. A small-scale approach will be used to interview people on an individual level. It must be shown that through these interviews, there will be emerging themes that apply to the greater population. This will be determined through thorough coding of the interviews and a brief comparison to existing survey data on a national level - albeit incomprehensive and limited.

\section{Human Subject Protections}

Imprisoned persons are a protected class. This research will only involve people who have already been released from prison. However, it is worth noting that this group of individuals overlaps with many vulnerable populations - and is, arguably, a vulnerable population themselves. Great care will be taken to protect the identity of participants and 
recordings will be destroyed post completion of the research. There is little personal risk from participating in this study. Portland State University IRB and the Multnomah County Research and Planning (RAP) team have both signed off on the project.

As the literature has shown, there is inherent corruption within the justice system in the United States. This poses a potential risk for participants if they were identified. Participant identities will be kept confidential for this project. Recordings will be made, but the utmost care will be taken to refrain from recording identifying information, and said information will never be written down. Recordings will be kept on a secure drive and destroyed upon completion of the study.

\section{Study Design}

This is an exploratory research project that will employ primary research methods in the form of one-on-one interviews (see the Appendix for the interview guide). The proposed sample size is 25 participants, but is subject to change depending on what emerging trends come out of the interviews.

Grounded theory will be utilized to explore participants' perception of the healthcare that they received while imprisoned in an Oregon male prison. Grounded theory will allow a fluid approach that can change and build on what is learned from interviews. This approach is the most appropriate because of the lack of research done on healthcare in correctional 
facilities. As the literature has shown, the only established trends in correctional facility healthcare are broad and vague. This research will allow data collection to be specific to numerous people and to adjust to the commonalities that come forth naturally.

\section{Interviews}

Recognizing that participants' views cannot be replicated entirely, the interviews will attempt to understand their experience to the fullest extent possible. One-on-one interviews will be conducted with up to twenty-five individuals. The interview will compare the person's health status before and throughout imprisonment, along with how they felt about the interactions they had with healthcare providers. A timeline of their health beginning before imprisonment and continuing throughout their time spent in prison will be constructed. The timeline will document how their health changed during that time: diagnosed diseases, prescribed medications, injuries, etc. Participants will be asked to describe their ability to access health care when it was needed, or desired.

The attempt is to ascertain what the perceived quality of healthcare is that these individuals received. The research also aims to begin assessing perceived risk to people's health from being imprisoned. The qualitative data collected, in conjunction with national medical data of inmates, will help concretize the quality of healthcare that is being offered in correctional facilities. The finalized report will be presented to Multnomah County with the hope of making 
recommendations as to what aspects of the correctional facility healthcare system could be improved.

Interview Topics.

Age and demographic information will be collected so that intersectional analysis can be performed. This information will illuminate further health inequities that may exist within correctional facility healthcare.

Participants will be asked for the length of time that they were imprisoned. This information will help to inform subsequent questions, as well as another measure for intersectional analysis. This detail will allow the health effects of imprisonment to be analyzed as a deeper, interval-level measurement, rather than imprisonment as a dichotomous variable.

A baseline will be established of what the participant's health was like before they were imprisoned. This baseline is a necessary starting point so that changes over the course of their time in prison can be accurately contrasted to their health status prior to, and throughout, imprisonment.

Using a timeline map (see Appendix $X$ for a copy of the timeline map to be used), the participant will be guided through their time in prison and asked to describe how their health changed. Prompts will be used to aid the participant in keeping their timeline straight: 
chronological chunks, i.e. beginning, middle, and end; notable events such as transfers, injuries, medication changes, etc. Participants will be asked about the process to access a physician and how long that took. These questions will establish the perceived level of quality of the healthcare received. How much people are able to maintain or not maintain their baseline health throughout their time in prison, will help show what health care is being provided and what is lacking.

Participants will be asked if they were ever refused care, and about how they were treated by the healthcare professionals that they did see. Descriptions of these events and interactions will be asked for. These questions are aimed at understanding how much stigma people endure while imprisoned, and how that stigma may affect the health care that they receive. As shown in the literature, this stigma and the effect it has on the health care provided, has a direct effect on people's health.

One to two questions will be used to address mental health status. Participants will be asked if they were treated for mental health while imprisoned, and if they plan to seek out or continue to get mental healthcare now that they have been released. As noted in the limitations section found below, mental health is a large issue that this compact pilot study cannot responsibly undertake. However, it is important to address. This information will allow a 
simple, intersectional analysis that gives credence to the rampant problem in our correctional facilities, and will show the need for further investigation.

The interview will end by asking the participant how they think their health will change now that they have been released. This question is aimed at understanding an overall mindset and perception of what people think the risk to their health was being imprisoned, and if that risk is gone post-release.

\section{Sample Population}

The sample population for this pilot study will be individuals who have recently been released from long-term imprisonment (ten to twenty years) in an Oregon male prison. A Community Health Specialist from the Multnomah County Health Assessment and Treatment (HAT) team will approach their clients that meet the criteria to offer them participation in the study. This will allow participants to remain confidential, including from the interviewer if they do not wish to give any identifying information. The only imposed age requirement is that all participants are legal adults (eighteen years or older). However, given the length of imprisonment criteria, it is assumed that most participants will be middle- to old age. It is also to be noted, that while mental health is not a major focus of this study, it is likely that a number of participants will be dual diagnosed.

\section{Proposed Analysis}


The interviews will go through numerous rounds of coding. Interviews will initially be coded incident to incident. As multiple interviews are completed, open coding to identify repeating, key topics will be employed. Axial coding will be used to find emerging trends between incidents and key themes in responses. Constant comparative methods, as detailed by Glaser and Straus (1967), will be used throughout the duration of data collection to inform successive interviews, and recognize when saturation is reached. The final analysis will utilize selective coding to determine what the most prevalent, overarching data results are. All coding schemes will be included in the final report.

\section{Limitations}

From the literature previously reviewed, it is known that mental health is a pervasive issue in correctional facilities. Due to this research being a humble pilot study, the ability to measure and weigh mental health to the extent that is necessary, is unfeasible. The interview will briefly include mental health topics, but only enough to show that there is an association that deserves further, and in-depth, investigation.

The concept of risk that is explored, mostly by the last question of the interview guide, is only a brief look at this idea. It is of interest to the study to establish if there is a perceived health risk associated with being imprisoned, or release from long-term imprisonment. There is 
an expected association, and if the data supports that hypothesis, it is another aspect of the justice-involved population that should be evaluated.

\section{Implications and Future Direction}

This research will in no way eradicate the bias or mistreatment in correctional facilities.

It will add to the literature of what is known so that we can continue to home in on solutions.

By qualitatively focusing on the specified population - people who have been recently released from long-term imprisonment in an Oregon male prison - and utilizing grounded theory, interventions can be explored. These transformations could be easily digestible, and even attainable here in Oregon. Additionally, by sharing these findings with the community and the Multnomah County HAT Team, it is expected that actionable items could come out of this pilot study.

In the future, a larger study that looks at similar topics, but quantitatively, would be invaluable. A mixed methods approach is, arguably, the best practice for understanding this problem. The ability to access medical records along with collecting affidavits from correctional facility workers: current inmates, releasees, officers, physicians, wardens, etc. could illustrate and realize the quality of healthcare that is truthfully being provided in correctional facilities. The physical data of medical records cements inmates' and releasees' accounts. Statements 
from those working in the facility can shed light on the internal workings of these systems and aid in discerning where the cracks lie. 


\section{References}

Aiken, J. (2017). Era of Mass Expansion: Why State Officials Should Fight Jail Growth. Prison Policy Initiative. https://www.prisonpolicy.org/reports/jailsovertime.html

American Heart Association. (2018). CDC Prevention Programs. American Heart Association. https://www.heart.org/en/get-involved/advocate/federal-priorities/cdc-preventionprograms

AZQuotes. (2017). Joe Arpaio Quotes. Retrieved from http://www.azquotes.com/author/566Joe_Arpaio.

Ballotpedia. (2020). Prison inmate release responses in response to the coronavirus (COVID-19) pandemic, 2020. Ballotpedia.org. https://ballotpedia.org/Prison_inmate_release_responses_in_response_to_the_corona virus_(COVID-19)_pandemic,_2020

Bandura, A. (1986). Social foundations of thought and action: A social cognitive theory (Prentice-Hall series in social learning theory). Englewood Cliffs, N.J.: Prentice-Hall.

Bandura, A. (2016). Moral disengagement: How people do harm and live with themselves. New York: Worth Publishers.

Barr, W. (2020, March 26). MEMORANDUM FOR DIRECTOR OF BUREAU PRISONS: Prioritization of Home Confinement as Appropriate in Response to COVID-19 Pandemic [Memorandum]. Department of Justice: Office of the Attorney General. 
https://www.themarshallproject.org/documents/6820452-Memorandum-fromAttorney-General-to-BOP-re-Home

Binswanger, I. A., Stern, M. F., Deyo, R. A., Heagerty, P. J., Cheadle, A., Elmore, J. G., \& Koepsell, T. D. (2007). Release from Prison - A High Risk of Death for Former Inmates. New England Journal of Medicine, 356(2), 157-165. doi: 10.1056/nejmsa064115

Braithwaite, R., Stephens, T., Treadwell, H., Braithwaite, K., \& Conerly, R. (2005). Short-term Impact of an HIV Risk Reduction Intervention for Soon-to-be Released Inmates in Georgia. Journal of Health Care for the Poor and Underserved, 16(4), 130-139.

Bureau of Justice Statistics [BJS]. n.d. Data Collection: Survey of Prison Inmates (SPI). Office of Justice Programs: Bureau of Justice Statistics. https://www.bjs.gov/index.cfm?ty=dcdetail\&iid=488

Centers for Disease Control and Prevention [CDC]. (2020). Coronavirus Disease 2019: Interim Guidance on Management of Coronavirus Disease 2019 (COVID-19) in Correctional and Detention Facilities. Centers for Disease Control and Prevention. https://www.cdc.gov/coronavirus/2019-ncov/community/correctiondetention/guidance-correctional-detention.html

Council on Ethical and Judicial Affairs. (1994). Ethical Issues in Health Care System Reform. American Medical Association. JAMA, 272(13), 1056-1062.

Cullen, F. T., Jonson, C. L., \& Nagin, D. S. (2011). Prisons do not reduce recidivism the high cost of ignoring science. The Prison Journal, 91(3 Suppl), 48S- 65S. 
Daniels, N. (1985). Just Health Care. New York: Cambridge University Press.

Daniels, N. (2012). Justice, Health, and Health Care. In Rhodes, R., Battin, M., \& Silvers, A. (Eds.), Medicine and Social Justice: Essays on the Distribution of Health Care (pp. 17-33). Oxford University Press, Incorporated.

Deitch, M. (2010). Independent correctional oversight mechanisms across the United States: A 50-state inventory. Pace Law Review, 30, 1754- 1930.

Durkheim, E., Solovay, S. A., Mueller, J. H., \& Catlin, G. E. G. (1964). The rules of sociological method (Eighth edition, First Free Press paperback ed., Free Press paperback). New York: Free Press of Glencoe.

Estelle v. Gamble, 429 U.S. 97 (1976).

Foucault, M. (1977). Discipline \& Punish: The Birth of the Prison (A. Sheridan, Trans.). Random House Inc. (Original work published 1975)

Garland, D. (1990). Punishment and Modern Society: A Study in Social Theory. The University of Chicago Press.

Goffman, E. (1961). Asylums: Essays on the social situation of mental patients and other inmates. New York: Anchor Books002E

Hammett, T. M., Harmon, M. P., \& Rhodes, W. (2002). The Burden of Infectious Disease Among Inmates of and Releasees From US Correctional Facilities, 1997. American Journal of Public Health, 92(11), 1789-1794. 
Haney, C. (2012). Politicizing crime and punishment: Redefining "justice" to fight the "war on prisoners". West Virginia Law Review, 114, 373- 414.

Hinton, E. (2016). From the War on Poverty to the War on Crime: The Making of Mass Incarceration in America. Harvard University Press. www.jstor.org/stable/j.ctvjk2w72.8

Infobase, film distributor. (2018). Language and Discrimination: Beyond Political Correctness. Avenue Consulting Ltd.

International Health Conference (2002). Constitution of the World Health Organization. 1946. Bulletin of the World Health Organization, 80(12), 983-984.

Jones, M., Kearney, G., Xu, X., Norwood, T., \& Proescholdbell, S. (2017). Mortality Rates and Cause of Death Among Former Prison Inmates in North Carolina. North Carolina Medical Journal, 78(4), 223-229.

Kanopy. (2016). Criminal Justice: Social Issues. San Francisco, California, USA]: Kanopy Streaming.

Karishma, C. A., Simon, A. E., DeFrances, C. J., \& Maruschak, L. (2016). National Survey of Prison Health Care: Selected findings (National health statistics reports; no. 96). U.S. Department of Health and Human Services; Centers for Disease Control and Prevention; National Center for Health Statistics.

Kim, V. (2014, June 4). Deputy tells of a culture of jail abuse; testimony comes in trial of six sheriff's officials charged with obstruction of justice. Los Angeles Times. https://www.pressreader.com/usa/los-angeles-times/20140604/282419872308797 
Kipnis, K. (2012). Social Justice and Correctional Health Services. In Rhodes, R., Battin, M., \& Silvers, A. (Eds.), Medicine and Social Justice: Essays on the Distribution of Health Care (pp. 373-384). Oxford University Press, Incorporated.

Muhammad, K. G. (2011). Where Did All the White Criminals Go?: Reconfiguring Race and Crime on the Road to Mass Incarceration. Souls, 13(1), 72-90. https://doi.org/10.1080/10999949.2011.551478.

National Academies of Sciences, Engineering, and Medicine. 2017. Improving Collection of Indicators of Criminal Justice System Involvement in Population Health Data Programs: Proceedings of a Workshop. Washington, DC: The National Academies Press. https://doi.org/10.17226/24633.

National Archive of Criminal Justice Data [NACJD]. (2019). Resource Guide: Survey of Inmates in State and Federal Correctional Facilities. ICPSR Institute for Social Research University of Michigan. https://www.icpsr.umich.edu/icpsrweb/content/NACJD/guides/sisfcf.html

National Center for Health Statistics. (2019). National Health Care Surveys: National Survey of Prison Health Care. Centers for Disease Control and Prevention. https://www.cdc.gov/nchs/dhcs/nsphc.htm

National Commission on Correctional Health Care [NCCHC]. (2002). Health Status of Soon-ToBe-Released Inmates: A Report to Congress: Volume 1. https://www.ncchc.org/filebin/Health_Status_vol_1.pdf 
National Research Council. (2014). The growth of incarceration in the United States: Exploring causes and consequences. Washington, DC: National Academies Press.

Nijhawan A. E. (2016). Infectious Diseases and the Criminal Justice System. The American journal of the medical sciences, 352(4), 399-407. https://doi.org/10.1016/j.amjms.2016.05.020

Park, K., \& Meagher, T. (2020, July 23). A State-by-State Look at Coronavirus in Prisons. The Marshall Project. https://www.themarshallproject.org/2020/05/01/a-state-by-statelook-at-coronavirus-in-prisons

Poblete, P. (2018). Court Affirms Maricopa County Sheriff's Office racial profiling ruling. Cronkite News Arizona PBS. https://cronkitenews.azpbs.org/2018/07/31/court-affirmsmaricopa-county-sheriffs-office-racial-profiling-ruling/

Porter, L. (2014). Incarceration and Post-release Health Behavior. Journal of Health and Social Behavior, 55(2), 234-249. www.jstor.org/stable/43186894

Rawls, J. (1971). A Theory of Justice. Cambridge, MA: Harvard University Press.

Rawls, J. (2013) A Theory of Justice (O. Höffe, Ed. \& J. den Hann, Trans.). Brill. (1971).

Restum, Z. G. (2005). Public health implications of substandard correctional health care. American Journal of Public Health, 95(10), 1689-91. http://stats.lib.pdx.edu/proxy.php?url=http://search.proquest.com.proxy.lib.pdx.edu/d ocview/215091321 ?accountid=13265. 
Rhodes, R., Battin, M., \& Silvers, A. (2012). Introduction. In Rhodes, R., Battin, M., \& Silvers, A. (Eds.), Medicine and Social Justice: Essays on the Distribution of Health Care (pp. 1-14). Oxford University Press, Incorporated.

Robertson, J. E. (2015). Recent Legal Developments: Correctional Case Law: 2014. Criminal Justice Review, 40(2), 258-271. https://doi.org/10.1177/0734016815586249.

Rothman, David J. 1971. The Discovery of the Asylum: Social Order and Disorder in the New Republic. Little, Brown and Company.

Sieck, C. J., \& Dembe, A. E. (2011). Results of a pilot study of pre-release STD testing and inmates' risk behaviors in an Ohio prison. Journal of urban health: bulletin of the New York Academy of Medicine, 88(4), 690-699. https://doi.org/10.1007/s11524-011-9565-6

Smith, L. (Director). (2008). In Sickness and In Wealth (Season 1, Episode 1) [TV series episode]. In L. Adelman (Executive Producer), Unnatural Causes. California Newsreel; Vital Pictures, Inc.

Sonenstein, B. (2015a). Advanced Correctional Healthcare's Brutal Brand of Jailhouse Medicine. Shadowproof. Retrieved November 12, 2019, from https://shadowproof.com/2015/08/03/advanced-correctional-healthcares-brutalbrand-of-jailhouse-medicine/.

Sonenstein, B. (2015b). Advanced Correctional Healthcare Doctor Faces Multiple Federal Lawsuits. Shadowproof. Retrieved November 12, 2019, from 
https://shadowproof.com/2015/08/10/advanced-correctional-healthcare-doctor-facesmultiple-federal-lawsuits/.

Sonenstein, B. (2015c). Private contractor deliberately ignored medical needs of Kentucky inmate: lawsuit. Prison Protest. Retrieved November 30, 2019, from http://prisonprotest.com/2015/03/13/private-contractor-deliberately-ignored-medicalneeds-of-kentucky-inmate-lawsuit/

The Nuremberg Code. (1949). "PERMISSIBLE MEDICAL EXPERIMENTS" in Trials of War Criminals before the Nuremberg Military Tribunals under Control Council Law No. 10, Vol. 2, pp. 181-182. Washington, D.C.: U.S. Government Printing Office.

The Sentencing Project. (2019). Fact Sheet: Trends in US Corrections. https://www.sentencingproject.org/wp-content/uploads/2016/01/Trends-in-USCorrections.pdf

U.S. Const. amend. IIIV.

United States v. DeCologero, 821 F.2d 39, 43 (1st Cir, 2008).

Wagner, P., \& Widra, E. (2020, March 27). Five Ways the Criminal Justice System Could Slow the Pandemic. Prison Policy Initiative. https://www.prisonpolicy.org/blog/2020/03/27/slowpandemic/

Wallace, G. N. (2012, September 22). The real lethal punishment: The inadequacy of prison health care and how it can be fixed. Retrieved November 12, 2019, from Faulkner Law 
Review website: https://link-galegroup-

com.proxy.lib.pdx.edu/apps/doc/A329899676/AONE?sid=Ims.

Weill, J., \& Haney, C. (2017). Mechanisms of Moral Disengagement and Prisoner Abuse.

Analyses of Social Issues and Public Policy, 17(1), 286-318.

https://doi.org/10.1111/asap.12142.

Welsh, B., Farrington, David P, \& Sherman, Lawrence W. (2001). Costs and benefits of preventing crime (Crime \& society (Boulder, Colo.)). Boulder, Colo.: Westview Press.

Widra, E., \& Hayre, D. (2020, June 25). Failing Grades: States' Responses to COVID-19 in Jails and Prisons. The Prison Policy Initiative. https://www.prisonpolicy.org/reports/failing_grades.html

Williams, B., Ahalt, C., Cloud, D., Augustine, D., Rorvig, L., \& Sears, D. (2020, March 26). Correctional Facilities In The Shadow Of COVID-19: Unique Challenges And Proposed Solutions. Health Affairs Blog. doi: 10.1377/hblog20200324.784502

Wilper, A. P., Woolhandler, S., \& Boyd, J. W. (2009). The Health and Health Care of US Prisoners: Results of a Nationwide Survey. American Journal of Public Health, 99(4), 666-672. https://doi.org/10.2105/AJPH.2008.144279.

World Health Organization. (2020). Cancer: Cancer Prevention. World Health Organization. https://www.who.int/cancer/prevention/en/ 


\section{Appendix}

Interview Guide

What is your age?

What is your race or ethnicity?

How long were you incarcerated (in prison)?

- Prompts: Was this one continuous period or were you in and out during that time? How long was your last / longest incarceration period?

Can you tell me about your health before you went to prison?

- Prompts: were you on medications? Had you been diagnosed with any chronic diseases, like heart disease, diabetes, cancer, asthma or other respiratory disease, etc? Had you been diagnosed with a mental illness, like depression, anxiety, schizophrenia, etc?

Can you tell me about your health over the course of your incarceration? ( 2 timeline sheets)

- Prompts: Were you ever transferred?

- " "First, let's talk about when the chunk of time when you were first sent to prison..." (repeat for middle and end of incarceration timeline)

- Prompts (beg / mid / end): were you diagnosed with anything - physical or mental? Were you put on any medications? Were you ever injured? Were you able to see a healthcare professional when you needed / wanted to? Was it easy to see a healthcare professional when you wanted to? Was there ever a long wait to see a healthcare professional? Were you able to just walk into the infirmary or did you have to make a request - for physical or mental healthcare?

Was there a time when you wanted or needed healthcare but did not get it?

- Prompts: What happened - was care withheld or not sought? Why?

Did the healthcare professionals you saw treat you well and with respect?

- Prompts: go through each prison they reported being in and see if there are differences in care

Will you seek out (or continue to get) mental health care now that you have been released?

How do you think your health is going to change now that you have been released?

- Prompts: get better or worse? Why? 